\title{
Colonial Theodicy and the Jesuit Ascetic Ideal in José de Acosta's Works on Spanish America
}

\author{
Bryan Green
}

This chapter aims to demonstrate the centrality of the problem of theodicy in José de Acosta's (1540-160o) scientific, ethnographic, and historical writings on Spanish America. ${ }^{1}$ Based on Acosta's experience as the Jesuit provincial of Peru and his active participation in the political and ecclesiastical reforms initiated under the viceroy Francisco de Toledo $(1515-82)$, these works bear witness to the moral evils running rampant among his fellow Spaniards and the concomitant suffering inflicted upon the indigenous population. ${ }^{2}$ While Acosta recognizes the moral evil at the root of Spanish sovereignty, namely greed in the ruthless pursuit of precious metals, his colonial theodicy nevertheless maintains that this evil is a means to the greater good of the Amerindian's salvation. In his guidelines for missionary conduct, Acosta offers a response to this ethical impasse through the performance of a distinctly Jesuit ascetic ideal, which

1 This chapter was written at the Pontificia Universidad Católica de Valparaíso with the support of a research grant from the Chilean government (FONDECYT Iniciación en Investigación no. 11140527, 2014-17).

2 The son of a prosperous merchant from Medina del Campo in Spain, Acosta entered the Society in $155^{2}$ and completed the first years of his studies at the Jesuit college in his hometown. Having distinguished himself as a student and grammar teacher in several Jesuit schools throughout Iberia, Acosta moved on to study philosophy and theology at the renowned University of Alcalá de Henares in 1557. After years of petitioning Jesuit authorities in Rome, he was sent to Peru as a preacher and theology professor in 1571. In Peru, Acosta directly participated in Toledo's reforms, traveled extensively throughout the viceroyalty, oversaw the Jesuit reduction at Juli (the model for future Jesuit missions throughout Spanish America), acted as the Jesuit provincial from 1576 to 1581 , and authored the acts of the Third Council of Lima (1582-83), which provided the foundation for his most important works on the Americas. After a year's sojourn in Mexico, Acosta returned to Europe in 1587 and remained embroiled in the political and theological controversies surrounding the Society of Jesus until the end of his life. Upon returning to Spain, Acosta published his De procuranda Indorum salute in 1589 and the Historia natural y moral de las Indias, the work for which he is best known, in 1590. Though primarily an apologetic account of Acosta's "Renaissance theological humanism," Claudio M. Burgaleta, S.J., has authored the most complete biography of the sixteenth-century Jesuit available in English: Claudio Burgaleta, José de Acosta, S.J. (1540160o): His Life and Thought (Chicago: Loyola Press, 1999).

(C) BRYAN GREEN, 2016 | DOI 10.1163/9789004313354_008

This is an open access chapter distributed under the terms of the Creative Commons Attribution-

Noncommercial-NonDerivative 3.o Unported (CC-BY-NC-ND 3.o) License. 
combines active and contemplative vocations in the execution of the order's inner-worldly activities, and thus reaffirms the moral foundation of the evangelical enterprise in the face of the radical evil that underlies Spanish political dominion. The prolific corpus of Jesuit writings from colonial Spanish America, particularly missionary chronicles and hagiography, can thus be read as symbolic acts which attempt to resolve this fundamental theological and philosophical problem through the actualization of a uniquely Jesuit vocation rooted in the Christian tradition and adapted to the context of early modern colonial rule. ${ }^{3}$

Although Acosta does not submit the problem of evil to a strictly philosophical or theological treatment in his works on the nature and nations of the New World, he does forward a strong theodicy in his recognition of concrete, horrific, and seemingly senseless evils that are justified as part of God's providential plan for bringing about a greater good. ${ }^{4}$ Succinctly put, Acosta denounces

3 On the uniqueness of the Jesuit vocation as a rejection of the cloister for more inner-worldly apostolic activities, see John W. O'Malley, The First Jesuits (Cambridge, MA: Harvard University Press, 1993), 62-69. William Bangert (d.1985) cites Jerónimo Nadal's epigrammatic "spiritu, corde, practice" as summarizing the Jesuit vocation as serving "God by his alertness to the inspirations of the Holy Spirit, by his loving and ardent acceptance of his mission, and by the embodiment of his aspirations in solid and practical action." William Bangert, Jerome Nadal, S.J., 1507-1580: Tracking the First Generation of Jesuits (Chicago: Loyola Press, 1992), 218. In her recent work on Jesuit spirituality in the age of global expansion, J. Michelle Molina employs phenomenology and affect theory to demonstrate how Ignatius's Spiritual Exercises fomented a modern sense of self through the embodiment of a particular Christian vocation combining both active and contemplative dimensions. Molina maintains that the Spiritual Exercises united the Jesuits' global apostolic vocation with a method of self-scrutiny and Christian piety. This uniquely Jesuit ethic, according to Molina, was predicated upon the circulation of bodies and texts throughout the Society's global network and was popularized through the order's multifarious activities in both Europe and the Americas. J. Michelle Molina, To Overcome Oneself: The Jesuit Ethic and the Spirit of Global Expansion (Berkeley: University of California Press, 2013), 25-31. I would add that this Jesuit ethic likewise offered a unique resolution to the problem of evil, which addressed the fundamental, and disquieting, relation of bodies in the new and expanding networks of global exchange. This confrontation with radical evil in the colonial world was essential to the articulation of action and discourse in Jesuit writing.

4 Though the term refers to a fundamental problem of religion and philosophy, "theodicy" is of relatively recent coinage, first appearing in the eponymous work (Essais de Théodicée, 1710) of Gottfried Wilhelm Leibniz (1646-1716), who derived the word from the Greek theos [God] and dike [justice]. As the German intellectual historian Ernst Cassirer (1874-1945) noted, the "riddle of theodicy" became a central preoccupation of Enlightenment philosophy upon rejecting the Augustinian doctrine of original sin, which subsequently gave way to an "empirical psychology" concerned with a rationalist calculus of pleasure and pain in human existence. 
the prevalence of moral evil among Spanish colonists and the concomitant suffering inflicted upon innocent Amerindians in the pursuit of wealth and power, yet he insists that God has used Spanish greed as a means to attract Christians to the New World and subsequently spread the Gospel, which the Jesuit deems an inestimable good. In Acosta's cosmological argument, there is nothing of the sophistication of the Jesuit theologian Francisco Suárez's (15481617) development of the "middle-knowledge" as a way to reconcile God's foreknowledge with human freedom to commit sinful acts. ${ }^{5}$ Nonetheless, through his missiological guidelines, Acosta adapts and develops the Jesuit vocation as a response to the contingencies of Spanish imperial expansion, in particular to the exceptional violence upon which Spanish sovereignty is founded.

When examined through Max Weber (1864-1920) and Clifford Geertz's (1926-2006) conceptions of religion as a symbolic system elaborated as a reference for ethical conduct in the face of crisis, Acosta's work is thoroughly theodical. According to Weber, the most basic religious need of any community is to satisfy the demand of the theodicy problem, which he defines as the ethical inquiry into the unequal and unjust distribution of fortune among God's servants, essentially addressing the need to justify human suffering and mortality. ${ }^{6}$ This fundamental dilemma for religion and culture is not only a problem of constructing a meaningful model of the world but more importantly that of providing an object to the will, that is, of reconciling ideal and material interests through purposive action. Though Weber focused on the Calvinist as the purest embodiment of the fusion of ethical and practical inner-worldly action, he also cited the Jesuit inner-worldly ascetic ideal as "a systematically formed

Though post-Kantian philosophy was generally dismissive of the problem, in the twentieth century theodicy became a concern for sociologists and anthropologists interested in how religion and culture provide a basis for meaningful action in all spheres of human activity. Not surprisingly, the problem of evil again became a concern for European philosophers following the Second World War, as evidenced by the work of Paul Ricoeur (1913-2005). In addition to its interest to contemporary Christian apologetics, such as the work of Alvin Plantinga (1932-), there is a renewed interest in theodicy as a central problem of early modern philosophers predating Leibniz. Ernst Casirrer, The Philosophy of the Enlightenment, trans. Fritz C.A. Koelin and James P. Pettegrove (Princeton: Princeton University Press, 1968), 137-6o. Elmar J. Kremer and Michael J. Latzer, introduction to The Problem of Evil in Early Modern Philosophy (Toronto: University of Toronto Press, 2001), 3-9.

5 Alfred J. Freddoso, "Suárez on God's Causal Involvement in Sinful Acts," in The Problem of Evil in Early Modern Philosophy, ed. Elmar J. Kremer and Michael J. Latzer (Toronto: University of Toronto Press, 2001), 29-33.

6 Max Weber, "The Social Psychology of World Religions," in From Max Weber: Essays in Sociology, trans. Hans Gerth and Charles Wright Mills (New York: Oxford University Press, 1946), 270. 
method of rational living, its aim being to overcome the status naturae, to release man from the power of irrational impulses and from dependency on the world and nature, to subject him to the supremacy of the purposeful will, and to subordinate his actions to his own continual control and to the consideration of their ethical consequences." ${ }^{7}$ In a world of manifest and horrific injustice, the Jesuit ascetic ideal that Acosta adapted to the contingencies of Spanish America legitimated action by posing both the corrupt colonial and the recalcitrant Amerindian as obstacles to overcome in a trial of the will that would ultimately reaffirm the providential order realized through the Spanish occupation of the New World. ${ }^{8}$

While Geertz notes Weber's monotheistic bias in examining the problem of suffering and the problem of evil as one and the same, he nevertheless adopts Weber's view of religion as essentially addressing the problem of meaning through symbolic action. ${ }^{9}$ For Geertz, religious texts and rituals are cultural performances that serve as models for and of the world, that is, they not only

7 Max Weber, The Protestant Ethic and the Spirit of Capitalism, trans. Talcott Parsons (New York: Routledge, 1992), 81.

8 Using Weber's sociology of religion as a starting point, the Spanish philosopher and historian José Luis Villacañas (1955-) analyzes the foundation and development of the Society against the backdrop of Spain's imperial ambitions. Villacañas argues that the strictly regimented production of spiritual consolation carried out between director and exercitant in the Spiritual Exercises reflects the order's contribution to the ethical rationalization of the modern secular worldview, not through an economic ethic, but rather through internalized relations of worldly power. As the Jesuit subject was both director and exercitant, he embodied both the ideal of charismatic direction of conscience and the submission to authority and the exercise of an inner-worldly vocation: "Hombres que a la vez," explains Villacañas, "son directores soberanos y siervos dirigidos y que, en uno y otro caso, reconocen una decisión sobre lo concreto, propia o ajena, asentada en la buena conciencia y en la certeza de ser instrumentos de Dios encaminados a su gloria" [Men who are at the same time sovereign directors and subordinate exercitants, and who in both cases recognize a decision over the concrete, which is founded on a clear conscience and the certainty of being instruments of God guided towards his glory]. José Luis Villacañas, ¿Qué imperio? Un ensayo polémico sobre Carlos Vy la España imperial (Madrid: Almuzara, 2008), 428-57.

9 Clifford Geertz, The Interpretation of Cultures (New York: Basic Books, 1973), 105-6. Geertz suggests that the two problems reflect the affective and ratiocinative dimensions of religious ethics: "For where the problem of suffering is concerned with threats to our ability to put our 'undisciplined squads of emotion' into some sort of soldierly order, the problem of evil is concerned with threats to our ability to make sound moral judgments. What is involved in the problem of evil is not the adequacy of our symbolic resources to govern our affective life, but the adequacy of those resources to provide a workable set of ethical criteria, normative guides to govern our action" (106). 
reflect the social order but also attempt to shape this order through symbolic action. Acosta's work epitomizes this enactment of a religious tradition as means of rescuing order from contingency. In fact, his cosmological argument is aptly summarized by Geertz's definition of the religious response to the problem of evil: "the formulation, by means of symbols, of an image of such genuine order of the world which will account for, and even celebrate, the perceived ambiguities, puzzles, and paradoxes of human experience."10 Nevertheless, Acosta's colonial theodicy does not simply stop at expressing awe at the workings of providence. As a basis for inner-worldly activities complicit with Spanish dominion, Acosta's theodicy implied a thorough examination of conscience, a methodical discipline in daily affairs, a thoroughgoing respect for hierarchies, and the assurance of a God-willed vocation as a means to achieving goals that were in the last instance performed ad maiorem Dei gloriam.

In addition to the focus on Acosta's euro-centric theory of cultural evolution and alphabetic writing, most contemporary readings of Acosta's works on Spanish America have focused on his taxonomy of pre-Hispanic idolatries and insistence on diabolic intervention in the New World. ${ }^{11}$ In his study of diabolism and commodity fetishism from the colonial period to twentieth-century Spanish America, the anthropologist Michael Taussig (1940-) cites Acosta as an example of the dualism that pitted Christian virtues against the demonically inspired vices of the Amerindian: "For the Spaniards the world could be said to be divided into two opposed parts, the virtues and the vices. Christians cultivated virtue, and the infidels fomented evil—the servants of God and the agents of the devil, locked in a death struggle."12 However, this is a reductionist reading of the Jesuit's thought on the problem of evil; in fact, in its association of greed and exploitation of Amerindian labor for personal gain, Acosta's theodicy

$10 \quad$ Ibid., 108.

11 David Brading, The First America: The Spanish Monarchy, Creole Patriots and the Liberal State (New York: Cambridge University Press, 2004), 188. Jorge Cañizares-Esguerra, How to Write the History of the New World (Stanford: Stanford University Press, 2001), 70-73. Fernando Cervantes, The Devil in the New World (New Haven: Yale University Press, 1994), 26-27. Sabine MacCormack, Religion in the Andes: Vision and Imagination in Early Colonial Peru (Princeton: Princeton University Press, 1991), 249-80. Walter D. Mignolo, The Darker Side of the Renaissance: Literacy, Territoriality and Colonization (Ann Arbor: University of Michigan Press, 2003), 83-86. Anthony Pagden, The Fall of Natural Man: The American Indian and the Origins of Comparative Ethnology (Cambridge: Cambridge University Press, 1982), 146-97.

12 Michael Taussig, The Devil and Commodity Fetishism in South America (Chapel Hill, NC: University of North Carolina Press, 2010), 169 . 
is much closer to the pre-capitalist critique of the market economy found in the religious practices studied by Taussig. Moreover, Fermín del Pino Díaz, the editor of the latest edition of Acosta's Historia natural y moral (1590), has argued that many of the Jesuit's comments on demonic influence are strategically placed in order to appease the Inquisition, which would have otherwise censored his detailed descriptions of Amerindian religious practices. ${ }^{13}$ While Acosta's work remains imbued with a belief in demonic influence, particularly with respect to pre-Hispanic religious practices, these studies have overlooked the fact that Spanish greed and cruelty figure just as prominently as manifestations of evil in Acosta's works on the Indies. In fact, in De procuranda Indorum salute, Acosta explains that "the devil, the enemy of the human race," employs three primary impediments to the propagation of the faith, the first of which is the conduct of many arrogant, greedy, lustful, and cruel Spaniards. ${ }^{14}$ Thus, Acosta explicitly links the workings of the devil in the New World with the moral evil of his fellow Spaniards.

For Acosta, the violence perpetrated in the New World is evental, that is, it is associated with an unprecedented historical rupture as the underside of the new global order ushered in by the "discovery" of the Americas. In Chapter 12, book 1 of De procuranda, aptly titled "Violence, a Serious Obstacle to the Faith," Acosta describes the extent of Spanish greed and savagery, declaring that "never was there such cruelty in any invasion of the Greeks among the Barbarians." ${ }^{15}$ Assuring his readers that he could cite a litany of similar incidents, "which are neither unknown nor exaggerated by the fantasy of historians," Acosta goes on to describe a specific case as related to him by a reliable witness:

An eyewitness, who had participated in the war against the Incas in this territory, told me with tears and despair of how it was a common practice to place in the public square women hanging from the gallows, whose infant children were likewise hung from cords piercing their breasts so that as the mothers were subjected to the torment of strangulation they

13 Fermín del Pino Díaz, introduction to José de Acosta, Historia naturaly moral de las Indias (Madrid: Consejo Superior de Investigaciones Científicas, 2008), xxxviii-xxxix.

14 José de Acosta, De procuranda Indorum salute, in Obras de P.José de Acosta de la Compañía de Jesús, ed. P. Francisco Mateos (Madrid: Atlas, 1954), 457.

15 José de Acosta, De procuranda Indorum salute, ed. Luciano Pereña (Madrid: Consejo Superior de Investigaciones Científicas, 1984), 1:193. "Vix enim in ulla vel graecorum vel barbarorum irruptione ita unquam saevitum est." All quotations from De procuranda are my translations from the Spanish in Pereña's bilingual edition. From here on I will include the original Latin in the footnotes for reference. 
would also be forced to be the instrument and witness of their own infants' strangulation. What an unheard of act of cruelty! ${ }^{16}$

While the overall condemnatory tone of Chapters 11, 12, and 13 of the first book of De procuranda and other evidence of Spanish brutality was redacted from the 1589 edition of Acosta's work, as the Jesuit's modern editors note, this shocking passage remained from the original manuscript. ${ }^{17}$ Acosta likely used this anecdote as a rhetorical amplification chosen to move his audience, yet it is important to bear in mind his criticisms of Bartolomé de Las Casas (14841566) for abusing just such strategies in his condemnation of Spanish conquest. ${ }^{18}$ Moreover, Acosta explicitly frames the anecdote by excluding it from those "exaggerations" peddled by less scrupulous historians. Though the image defies allegorical interpretation, Acosta's description of this scene as "an unheard act of cruelty" ("novo crudelitatis exemplo") is conspicuous. This phrase, along with the statement comparing the ancient Greek incursions against the Barbarians, underscores the singular, new ("novo") mode of violence unleashed in the Americas, as if the dispute of the ancients and moderns no longer concerned the perfection of human knowledge in the age of discovery but rather the scale and intensity of violence ushered in with the new global order.

The use of "novo" to describe this unjustifiable act of cruelty likewise resonates with the original Latin title of Acosta's Historia natural y moral de las

16 Ibid. "Neque obscura res aut exagerationibus scriptorum amplifacata. In hoc ipso regno cum bellum gereretur adversus ingas, feminas in triviis ex alto suspensas ipsos suos infantulos uberibus perforatis pariter suspensos tenentes exponi solitas, ut uno supplicio strangulatae matres filiorum fieri suspendia cogerentur, novo crudelitatis exemplo, mihi narrabat dolenter ac luctuose qui et his interfuit et quorum pars magna fit."

17 Pereña, introduction, 21. The literary scholar Rolena Adorno (1942-) states that the censorship of De procuranda "reduced the work from a treatise on colonial ethics rooted in a historical perspective into a merely prescriptive guide to missionary pedagogy." Although Adorno exaggerates the extent of the censorship and the focus of the final published work, her characterization of Acosta's intent is accurate. Rolena Adorno, The Polemics of Possession in Spanish American Narrative (New Haven: Yale University Press, 2007), 208.

18 José de Acosta, Historia natural y moral de las Indias, ed. Fermín del Pino Díaz (Madrid: Consejo Superior de Investigaciones Científicas, 2008), 270. Don Paul Abbott, Rhetoric in the New World: Rhetorical Theory and Practice in Colonial Spanish America (Columbia, sc: University of South Carolina Press, 1996), 66-75. Burgaleta, José de Acosta, S.J., 106. Both Abbott and Burgaleta have focused on Acosta's rhetorical prescriptions and emphasis on affect in preaching to Amerindian neophytes, yet they have overlooked the many examples of amplification that Acosta uses in works intended for Christian European audiences. 
Indias (De natura Novi Orbis), which was originally the introduction to De procuranda and was later expanded and translated into Spanish in Europe for publication as a separate work. ${ }^{19}$ Considering Acosta's frequent yet undervalued use of irony and wordplay, this resonance with the advent of the New World and the unveiling of its nature to the European gaze was very likely intentional. The Historia natural y moral, in fact, begins by explaining that knowledge of the lands and peoples of the Americas was withheld from the ancients, "Yet now we can say that to the great joy of our times befell the realization of those to marvels: to wit, the navigation of the Ocean with great ease and man's enjoyment of the most temperate climate of the Torrid Zone" (23). ${ }^{20}$ While Acosta's works on the New World open with the triumphant historical vision epitomized by Hernando de Acuña's (1518-80) famous sonnet celebrating the "glorious age" reserved for the Spanish Empire under Charles v (r.1516-56), he likewise presents us with the horrific images from which Walter Benjamin's (1892-1940) angel of history inexorably retreats into the future of our present. $^{21}$

The violence decried by Acosta is evental not only as a historical rupture signaling a new age or, pace Benjamin, as a messianic claim on the present, but also as the crisis of a subject facing the contingency of radical evil. Acosta not only confronts the problem of evil but more broadly that of the unjustifiable. ${ }^{22}$ According to the French philosopher Paul Ricoeur (1913-2005), the unjustifiable

\footnotetext{
19 Pereña, introduction, 26.

20 Acosta, Historia natural y moral, 23.

21 Hernando de Acuña, "Al Rey Nuestro Señor," in Poesía lírica del Siglo de Oro, ed. Elías L. Rivers (Madrid: Cátedra, 2002), 109. Walter Benjamin, "Theses on the Philosophy of History," in Illuminations, trans. Harry Zohn, ed. Hannah Arendt (New York: Harcourt Brace, 1968), 253-64.

22 In an early essay on Jean Nabert's (1881-1960) Essai sur le mal, Ricoeur critically examines rationalist theodicies that would reduce evil to a violation of norms defining a rule-bound subjectivity. Instead of evil as such, Ricoeur, following Nabert, focuses on the unjustifiable as that which surpasses the bounds on any opposition between the valid or the invalid: "telle cruauté, telle bassesse, telle inégalité extreme dans les conditions sociales me bouleversent sans que je puisse designer les norms violées; ce n'est plus un symétrique que je comprendrais encore par opposition au valable; ce sont des maux qui s'inscrivent dans une contradiction plus radicale que celle du valable et du non valable et suscitent une demande de justification que le accomplissement du devoir ne satisferait plus" [such cruelty, such baseness, such extreme inequality of social conditions overwhelms me without being able to determine the norms that are violated; it is no longer the inverse of what I could still comprehend in opposition to the valid; these are evils that are inscribed within a more radical contradiction than that of the valid and invalid, and they provoke a demand for justification that the fulfillment of duty will never satisfy]. Paul Ricoeur,
} 
event reveals the impasse of a moral subject brought into being as an affirmation against the course of the world (the originary act of the will) at the same time that this affirmation is always already the recognition of a purer self never realized through contingent action. Just as this contingency produces a fissure between the pure and particular self, it likewise signals a rupture between individual subjects constituted through a relation of reciprocity. For Ricoeur, this double rupture within the self and between the self and other is constitutive of subjectivity and implies, contrary to Geertz's anthropological approach, a fundamental unity of the problems of sin and suffering. "All evil committed by one person," affirms Ricoeur, "is evil undergone by another. To do evil is to make another person suffer. Violence in this sense, constantly recreates the unity of moral evil and suffering." ${ }^{23}$ The reciprocity of evil within the unity of sin and suffering is present throughout Acosta's writings, particularly in his emphasis on the vice of greed and the pursuit of precious metals in the New World. This unity is explicit in Acosta's description of the infernal conditions in the silver mines of Potosí: "A horrible thing to behold and to even imagine: such is the love for money, in the pursuit of which so much is done and suffered."24 The unfettered desire for personal gain and the horrific suffering of the Amerindian are two aspects of the unjustifiable event that, for Acosta, has brought the New World into being and must be subsumed into an ethical framework for continuing the imperial and evangelical projects with a sense of legitimacy.

In De procuranda Indorum salute, Acosta returns to the hellish conditions of Amerindian laborers in Potosí and expounds his theodicy, in which ruthless greed and abject suffering are intimately linked. In a passage echoing his description of mining techniques in book 2 of the Historia natural, Acosta begins with a jeremiad condemning the greed and lack of compassion among his compatriots but ends with his astonishment at the mysterious workings of providence:

Seen from this perspective, I am not sure what would be better. On the one hand, I should denounce the calamity of our times in which charity has grown so cold, and faith is almost nowhere to be found on the face of

"L'Essai sur le mal," in Lectures 2: Le contrée des philosophes (Paris: Éditions du Seuil, 1999), 239.

23 Paul Ricoeur, "Evil, a Challenge to Philosophy and Theology," in Figuring the Sacred: Religion, Narrative, and Imagination, ed. Mark I. Wallace, trans. David Pellauer (Minneapolis, MN: Augsburg Fortress, 1995), 259.

24 Acosta, Historia natural y moral, 109. "Cosa horrible y que, en pensalla, aún pone grima: tanto es el amor del dinero, por cuya recuesta se hace y padece tanto." 
the earth, as cited in the Gospels. Is not the salvation of so many souls through the faith of Christ sufficient payment to awaken and move the souls of our people? Is gold and silver so important to us that, if they are not to be found, we are not interested in the salvation of souls? But on the other hand, one must profoundly admire the goodness and providence of God, who adjusts to the condition of mankind, and in order to attract such remote and barbarous nations to the Gospel he copiously endowed these lands with precious metals in order to awaken greed in our people. If charity towards other souls does not move us, will then our thirst for gold at least lure us? And just as the incredulity of the Israelites caused the salvation of the gentiles, so now the avarice of Christians is converted into the cause of the evangelization of the Indies. ${ }^{25}$

Acosta's colonial theodicy presents an approach to the problem of evil similar to Hegel's Aufhebung, the German philosopher's concept for the dialectical overcoming of error, which, according to Ricoeur, "makes the tragic and the logical coincide at every stage. Something must die so that something greater must be born. In this sense, misfortune is everywhere, but everywhere it is surpassed, to the extent that reconciliation always wins out over what is torn apart." 26 This providential dialectic-derived from a wager for coherence in the face of radical evil—provides an alternate genealogy for the transmutation of private vices into public benefits, generally attributed to late seventeenthcentury English political philosophy and the changing relations between the private and public spheres in Europe. ${ }^{27}$ Nevertheless, Acosta goes on to compare

25 Acosta, De procuranda Indorum salute, 1:533. "Equidem nescio utrum potius faciam, querarne nostrorum temporum calamitatem et charitatem refrigescentem fidemque raro in quoquam inventam iuxta Domini verbum, tot animarum milliaut Christo lucrifant non satis merces videri dignas quae nostrorum animos excitent, auri argentique cupiditatem longe plus valere apud nos, ut ista si desint, animarum salus pro nihil fiat? An vero Dei bonitatem summaque providentiam admirer qui pro nostrorum hominum ingenio, ut gentes adeo remotas et barbaras Evangelio adiungeret, aurum argentumque in his terris tam copiose donavit hisque veluti illexit nostrorum cupiditatem, ut si charitas non invitaret animarum, auri saltem cupiditas inescaret? Et quemadmodum olim incredulitatis Israelis salus fuit gentium, ita nunc christianorum avaritia indorum vocatio facta est."

26 Ricoeur, "Evil, a Challenge to Philosophy," 256.

27 Acosta by no means condones these vices, nor does he relegate them to a private sphere beyond the intervention of the state. Nevertheless, his reconciliation of moral evil with a providential design for the New World is taken a step further by the early seventeenth century. Acosta's near-contemporary Bernardo de Balbuena's (1562-1627) early Baroque ode to Mexico City, Grandeza mexicana (1604), perhaps stakes the most legitimate claim 
the suffering of the Amerindian with the Roman persecution of Jerusalem, and declares that God often "shows wrath with his own people and mercy with foreigners" in order to realize a greater good. ${ }^{28}$ This analogy undermines the dualist, triumphalist interpretation of Acosta's work: here the Jesuit subtly recasts the Amerindians as God's chosen people and the Spaniards as pagan invaders.

Though Acosta insists on the moderate use of coercive violence as a means of preserving Spanish sovereignty and forwarding the conversion of the Amerindian, he repeatedly references the illegitimate and morally corrupt foundations of Spanish dominion. For example, in the Historia naturaly moral, Acosta candidly remarks that the "idolatry" of precious metals was not as prominent among the Amerindians as among "those bad Christians that have committed great excesses in pursuit of gold and silver."29 Acosta's explicit linking of the Spanish obsession with precious metals and the evil of idolatry is particularly remarkable in light of his extensive and oft-cited categorization of Amerindian idolatries in book 5 of the Historia natural y moral. ${ }^{30}$ Nevertheless,

as a precursor to Bernard Mandeville's (1670-1733) Fable of the Bees (1705). Balbuena celebrates the pursuit of self-interest as the force behind the greatness of Mexico City, not only in arts, architecture, and manufactures but also in holiness: "Por todas parte la codicia a rodo/Que ya cuanto se trata y se practica/Es interés de un modo o de otro modo/Este es el sol que al mundo vivifica/Quien lo conserva, rige y acrecienta/Lo ampara, lo defiende y fortifica" [On all sides greed abounds/For all that is done or dealt/Is somehow in one's self-interest/For his is the sun that warms the world,/Conserving, ruling, and increasing/ Sheltering, defending, and fortifying all]. The Mexican poet and essayist Octavio Paz (1914-88) observed the strangeness of this paean to the vices of urban life, which starkly contrasts with the Spanish pastoral tradition from Garcilaso de la Vega (1501-36) to Luis de Góngora (1561-1627), yet Balbuena's moral vision seems a natural evolution of Acosta's providential dialectic, and even foreshadows the predominant moral vision of modern political economy. Bernardo de Balbuena, Grandeza mexicana y fragmentos del Siglo de Oro y el Bernardo (México, DF: Ediciones de la Universidad Autónoma, 1954), 15. Octavio Paz, Sor Juana Inés de la Cruz, o las trampas de la fe (México: Fondo de Cultura Económica, 1983), 72-73.

28 Acosta, De procuranda Indorum salute, 1:533-35.

29 Acosta, Historia natural y moral, 98.

3o Acosta, of course, was not the first to suggest that the Spanish conquistadors' pursuit of precious metals was a form of idolatry. In his Brevísima relación de la destrucción de las Indias (1552), Bartolomé de Las Casas (1484-1566) famously ridiculed the Spanish idolatry of gold with the inclusion of a speech supposedly given by the Taino leader Hatuey. Whereas Las Casas links the Spanish desire of precious metals to idolatry through analogy, Acosta maintains that this desire is literally idolatrous and represents a moral evil underlying the new world order. A comparison between the positions of the Dominican 
the abundance of precious metals in the Indies that provokes this idolatry is, according to the Jesuit, further evidence of the "wisdom of the eternal Lord" who employs human vices as a means of spreading Christianity to regions of the world that otherwise offer no incentives to explorers, merchants, or empires. ${ }^{31}$ Using a colorful analogy, Acosta explains that just as the father of an ugly daughter must offer a generous dowry in order to interest suitors, so too has God endowed the Indies with precious metals in order to lure Christians to an otherwise unattractive land. ${ }^{32}$

If, as Acosta argues, the idolatry of precious metals is an evil God permits as a means to consummating a universal order, then what are we to make of Acosta's attribution of the proliferation of idolatries in pre-Hispanic America to the machinations of the "enemy of men"?33 From the outset of his "Moral History" of the Indies, Acosta informs his reader that he only intends to relate the history of the Indies prior to the arrival of the Spaniards, that is, "up to the doors of the Gospel," or the event that brings about the new order. ${ }^{34}$ Nevertheless, while describing the devil's free reign in the Americas prior to and outside of the universal order of Christendom, Acosta returns to that evil inside, or at the origin, of this order as a means permitted for the greater good. For example, Acosta turns to the vice of greed in his description of the cult of Quetzalcoatl in Cholula, which he portrays as a republic known for engaging in commerce both before and after the arrival of the Spanish conquistador Hernán Cortés (1485-1547). ${ }^{35}$ According to Acosta, the "cholulanos" worshipped the Nahuatl deity because of his power to bestow riches upon his followers, just like the cult of Mammon referenced in the New Testament: "And truly," asserts the Jesuit, "the name that the Cholulans gave their god was appropriate, although they did not understand it themselves: they called him Quetzalcoatl, which means 'serpent of rich plumage,' for such is the demon of greed." ${ }^{36}$ As if to drive home the subtle parallel with the Spanish desire for precious metals, Acosta returns to the Cholulan cult of Quetzalcoatl in the conclusion of book 5 , in which he offers a detailed description of the merchant festival dedicated to the Nahuatl deity. Acosta punctuates this description

and the Jesuit on the subject of idolatry and evil is the topic of a forthcoming work. Bartolomé de Las Casas, Brevísima relación de la destrucción de las Indias, ed. André Saint-Lu (Madrid: Cátedra, 1999), 91-92.

Ibid.

32 Ibid.

33 Ibid., 164.

34 Ibid., 151.

35 Ibid., 164.

36 Ibid. 
with a seemingly dualistic opposition between the Old and the New Worlds, or between Christianity and Amerindian idolatry: "For the same Spaniards, over there or wherever they may find themselves, this history may cause us to feel grateful to Our Lord God, giving infinite thanks for the great good of giving us his holy Law, which is entirely just, clean and beneficial. This is well recognized in comparison with the laws of Satan, under which so many wretches have lived." ${ }^{37}$ Yet this dualism does not necessarily neatly divide the Spanish from the Amerindian. Acosta ambiguously laments that such a great part of the world still lives in "blindness and darkness" and calls upon those with a Christian heart to "grieve for those who still continue on the path to their perdition, and to urge the father of mercy to reveal the treasures and riches of Jesus Christ, who with the Father and the Holy Spirit reigns for all eternity. Amen." ${ }^{38}$ Given Acosta's condemnation of Spanish vices throughout both the Historia natural y moral and De procuranda, he seems to weave an intentional ambiguity with regard to who exactly is on the path to perdition. The evocation of the "treasures and riches of Jesus Christ" suggests a direct opposition, not to Amerindian idolatry, but rather the ruthless pursuit of precious metals that Acosta views as the immediate cause of the Spanish occupation of the Americas.

The subtle reference to Spanish greed becomes more explicit in the conclusion of his "moral" history of the Indies, as Acosta describes the excesses of the Spanish soldiers left behind by Hernán Cortés in Tenochtitlan and their ignominious retreat during the so-called "Noche Triste." Acosta explains that the Spaniards were forced to fashion portable bridges to make their escape across the canals of the island city, but upon reaching the second canal "more than three hundred men fell wounded and trampled where today there is a shrine (impertinently and without reason) called the 'shrine of the Martyrs.' Many could not escape because of the jewels and gold they carried; others, who stopped to pick these up, were taken prisoner by the Mexicans and cruelly sacrificed before their idols." ${ }^{39}$ In stark contrast to the providential discourse of Hernán Cortés's official historian, Francisco López de Gómara (1511-64), who portrays the conquest of Tenochtitlan as a heroic enterprise in which military domination and evangelization seamlessly converged, Acosta focuses on the base motives of the Spanish soldiers and adds a heavy dose of indignation at the suggestion that the fallen should be considered martyrs. ${ }^{40}$ In concluding

\footnotetext{
$37 \quad$ Ibid., 198.

38 Ibid., 199 .

39 Ibid., 268.

40 Adorno, Polemics of Possession, 132-34.
} 
the "Moral History" with the fall of Tenochtitlan, Acosta seems to place the first wave of Spanish conquest prior to the "doors of the Gospel," which he announces as the temporal limit at the beginning of book 5 . However, this is an ambivalent threshold, as it does not neatly divide Spanish virtues and Amerindian vices; in fact, Acosta's historical relation would seem to place the evil of Spanish greed within the pre-history of the new global order ordained by Providence. Nevertheless, the moral evil of Spanish greed and cruelty persists as the exception permitted in order to bring about a new order that is never fully realized, as Acosta demonstrates throughout his works on the Americas.

In the concluding chapters of the Historia natural y moral, Acosta again emphasizes the excesses of the Spaniards during the first wave of conquest, but he reasserts his awe at the "marvelous designs" employed by God in order to spread his Gospel. ${ }^{41}$ In the final chapter, titled "On the Plan Ordained by Divine Providence for the Entrance of the Christian Religion in the Indies," Acosta brings together the two most prominent figurations of evil that appear throughout his work: the greed of Spanish conquerors and merchants, and the diabolic influence behind Amerindian idolatry. As had also been the case in the Mediterranean world during the first centuries of the Christian era, Acosta asserts that the existence of vast empires with their own lingua franca facilitated the spread of Christianity in the Indies; nevertheless, the Jesuit laments that this new wave of evangelization was spearheaded by "merchants and soldiers who with the fever of greed and worldly concerns search out and find new nations where we follow with our own merchandise." ${ }^{22}$ With an acid irony that is difficult to convey in translation, Acosta refers to the Gospel as mere "merchandise" that missionaries are obliged to trade following the lead of men solely concerned with worldly gains, but who eventually prove to be the means by which the Gospel is spread in modern times. ${ }^{43}$ Acosta goes on to argue that the Amerindians' "servitude and subjection to the devil" was likewise part of

\section{$41 \quad$ Ibid., 270.}

42 Ibid., 271.

43 In his analysis of the concluding chapters of the Historia natural y moral, the otherwise rigorous modern biographer of Acosta, Burgaleta, omits this explicit reference to the moral evil of Spaniards as a means to the fulfillment of a providential order alongside the diabolically inspired evils that existed in the Americas prior to the event of "discovery" (99-101). Acosta seems to contradict the doctrine of Aquinas on malum poenae [evil suffered] and malum culpae [evil done]: while the "Angelic Doctor" asserted that the former could be a lack of being used as the means to an eventual greater goodness, the latter could never be a means to an end within a providential plan. Brian Davies, Thomas Aquinas on God and Evil (New York: Oxford University Press, 2011), 117. 
the providential plan, "which from these very evils brings forth goods, and reaps his own good from another's evil, which he did not sow" (271). The Jesuit explains that those very nations that suffered under the yoke of Satan were the same who most warmly embraced the more just law of Christianity, even though this justice was only rarely on display, as Acosta demonstrates throughout his work. Furthermore, these nations were already vaguely familiar with Christian rites, as the devil had perversely mimicked communion, confession, and the triune deity through pre-Hispanic religious practices.

Curiously, Acosta's conjectures about the existence of a northern passage linking the Atlantic and Pacific oceans (the fabled Strait of Anian) are also framed within the colonial theodicy used to justify the moral evil underlying Spanish dominion. In this case, however, the immediate cause of a new providential order is not the expansion of the Spanish Empire spurred on by the desire for precious metals but rather the expeditions of the English pirate Francis Drake (1540-96). Acosta asserts that the "secret" of the northern passage will soon be revealed, for "it is a truth worthy of awe that just like little ants men will follow after the traces and reports of novelties until they come upon the sweetness of greed and human glory."44 The insect analogy emphasizes both the smallness of human ambitions in relation to the inscrutability of providential designs as well as the Jesuit's undisguised contempt for the vices run rampant in the New World. Acosta's reproachful tone is again eclipsed by his awe at the wisdom of a Creator who employs European vices as the means to "communicate the light of his holy Gospel to people who still live in the dark shadows of their errors." 45 This theodical argument, however, unexpectedly equates the expansion of the Spanish Empire with piracy, both, according to Acosta, driven by greed and lust for worldly power though unwittingly executing a divine will. Acosta thus raises the specters of those two fundamental enemies of the nomos of international law (the tyrant and the pirate) as the figures of a foundational violence upon which the sovereign decision, and the law itself, is based. ${ }^{46}$ Acosta explicitly addresses this problem in De procuranda:

\footnotetext{
44 Acosta, Historia natural y moral, 75 .

45 Ibid.

46 The German political philosopher Carl Schmitt (1888-1985) explains that the tyrant and the pirate represented complementary figures of the enemy that "not only obtained their meaning from, but affirmed the existence of the concrete order of the international law of empire." While Schmitt limits this complementarity to the medieval concept of imperium, the religious studies scholar Gil Anidjar argues that this medieval concept of spatialized enmity (i.e., a figure existing outside the legal order, an "outlaw") is fundamental to the political theorist's concept of a sovereign decision based on the exception or suspension of the law. Anidjar furthermore relates these two figures of the enemy to Saint
} 
"For what kingdom or empire is there that does not owe in great part its first origin to violence? It was not in vain that the Ancients used the same word to refer to kings and tyrants." ${ }^{\prime 7}$ As the Latin American literary scholar Ivonne del Valle argues, Acosta struggles with this fundamental political aporia throughout his work, if only to conclude that the evangelical project trumps the illegitimacy of Spanish dominion in the New World. ${ }^{48}$ Though the solution to the problem of Spanish sovereignty remains underdeveloped and unsatisfactory in Acosta's work, he nevertheless offers a partial resolution of this impasse through symbolic action, that is, through the performance of the missionary vocation detailed in De procuranda.

Throughout the De procuranda, Acosta details the implementation of the Jesuits' particular vocation of contemplatives in action, which called for an ascetic self-denial in the execution of spiritual, intellectual, and inner-worldly activities performed ad maiorem Dei gloriam. ${ }^{49}$ The guidelines elaborated in De procuranda are essentially instructions for a cultural performance that would bring order out of chaos through the actualization of an ascetic ideal deeply rooted in Christian tradition. In his call for stringent discipline, intellectual rigor, and irreproachable conduct among missionaries, Acosta not only applies the Jesuit vocation as a response to the intractable moral dilemmas of the Indies but also forwards an implicit rebuke to the opinion, expressed by no less an authority than Jerónimo Nadal (1507-80), that only less qualified Jesuits should be sent for missionary work in the Indies while

Augustine's equation of piracy and monarchy, which, as Anidjar notes, not only links the state of exception and sovereignty but also the global order of commerce and international law. Considering his often direct and acid criticism of Spanish conduct in the expansion of empire in the Americas, it is very likely that Acosta had Augustine's anecdote in mind when writing this passage. Carl Schmitt, The Nomos of the Earth in the International Law of the Jus Publicum Europaeum, trans. Gary L. Ulmen (New York: Telos Press Publishing, 2003), 65. Gil Anidjar, "Terror Right," New Centennial Review 4, no. 3 (Winter 2003): 59 .

47 Acosta, De procuranda Indorum salute, 1:401. "Quod enim regnum est, quod non violentia magna ex parte initio quaesitum sit? Ut non inepte pud veteres et reges et tyranni eodem nomine censeantur."

48 Ivonne del Valle argues that the contradiction between the violence of Spanish conquest and Acosta's faith in a providential order leads him to develop a third way between Machiavelli's realpolitik and Las Casas's utopianism, which she defines as the "Baroque as a Christian-political solution to the problem of dominion." Ivonne del Valle, "José de Acosta, Violence and Rhetoric: The Emergence of Colonial Baroque," Caliope 18, no. 2 (2013): 49 .

49 William V. Bangert and Thomas M. McCoog, Jerome Nadal, S.J., 1507-1580 (Chicago: Loyola University Press, 1992), 246-69. 
more talented candidates should be reserved for ministry in Europe. ${ }^{50}$ Citing Saint Ambrose (340-97), Acosta claims that the ministers chosen to govern both the civil and ecclesiastic spheres in Spanish America should be carefully vetted for their Christian virtue, as they are all "pedagogues" to the Amerindians through their example. ${ }^{51}$ As the success of the evangelical mission in the Americas depends upon the prior establishment of a civil order, Acosta argues that virtuous officials, both secular and ecclesiastic, are crucial. This model of virtue is performed not only against the foil of Amerindian idolatry but even more importantly as a counter-example to the rampant vices Acosta has observed among his fellow Spaniards.

According to Acosta, the missionary's example is especially important because of the lack of a tradition or institutions to guide the conduct of both colonizer and colonized: "Everything is new. There are no established customs. Except for natural law, the laws are not at all firmly set down. The traditions and examples from past times are either inexistent or unworthy of imitation."52 While this statement seems to suggest that the blame lies with pre-Hispanic customs, the Jesuit is equally severe with the colonizers' vices. Acosta relates a scene in which Amerindians ironically evoke a biblical verse to criticize the misconduct they observe in their Spanish overlords:

The very prophet Ezekiel, though he seems to speak of the people of Israel, with more certainty could be said to refer to the men of our age, when he attributes to God that lamentation: But when they came to the nations, wherever they came, they profaned my holy name, in that it was said of them, "These are the people of the Lord, and yet they had to go out of his land." A testimony to their disgust and disapproval, the gentiles frequently apply these words, full of irony, when they speak of us among themselves, and they even throw them in our faces when we chastise them excessively, because they see us doing the same things that we reprehend in them $(1: 411) .53$

$50 \quad$ Ibid., 244 .

$5^{1}$ Acosta, De procuranda Indorum salute, 1:403.

$5^{2}$ Ibid., 407. "Omnia nova, nullae consuetudines certae; leges iuraque omnia, naturali excepto, nihil propemodum firma; auctoritas exemplaque superiorum temporum vel nulla vel non imitanda."

53 Ibid., 411. "Propheta sane Ezechiel, etsi de suo Israele narrare videtur, verius tamen de nostri aevi hominibus vaticinari credendus est, cum illa divinie doloris et querimoniae plena pronuntiat: Et ingressi sunt ad gentes ad quas introierunt; et polluerunt nomen sanctum meum, cum diceretur de eis: populus Dei iste est, et de terra eius egressi sunt. Quas sane ironicas voces fastidii et despicentiae testes, cum inter se gentes de nobis saepissime 
It is not only the fact that Spaniards are the focus of the scrutinizing gaze of the Amerindian subject that makes the election of virtuous officials so important; the distance from the controlling gaze of both the sovereign and the pontifex also extends "a broad field of action for licentiousness and low passions." 54 The Americas then become a symbolic space for the exercise of self-discipline and control where the Amerindian would be edified by the example of his or her secular and ecclesiastic authorities, and where the very justification of Spanish rule was put on trial against the backdrop of customs and cultures that required an absolute reform. This performance is nonetheless trapped in a double-bind: while the missionary ostensibly embodies a model of virtue in order to draw the Amerindian away from the darkness of pre-Hispanic idolatry into the light of Christianity, the example extolled by Acosta derives its symbolic potency in relation to the Spanish vices that paradoxically undergird this evangelical project.

In his reaffirmation of the evangelical virtues of chastity, poverty, and obedience, Acosta indirectly reflects the lack of strict observance among his peers. Interestingly, Acosta again turns to greed as the most nefarious vice among Christian apostles in the New World: in the chapter titled "On Chastity and the Necessary Sacrifices for Preaching the Gospel," he declares, "But if the depravity of lust makes the apostle despicable, the filth of greed makes him hateful." 55 The contrast of Acosta's ideal missionary with the reality of the Americas is reflected in a supposed dialogue, between himself and an unnamed priest from Callao, in the viceroyalty of Peru. In this dialogue, Acosta criticizes the priest not only for his avarice and lust but also for his ignorance of the language spoken by his catechumens, concluding that Amerindians may be condemned for their infidelity but that a much more severe judgment awaited this remiss apostle. ${ }^{56}$ Acosta impugns not only the priest's lack of virtue but also his ignorance: he has not taken the time to observe, study, and master the language of his catechumens in order to draw them into the fold. ${ }^{57}$ In addition

usurpant, tum vero cum acrius obiurgantur etiam in os nobis iactare non verentur, eadem quippe ipsi agimus quae in illis maxime reprehendimus."

54 Ibid., 409. "licentiae ac libidini praefectorum campus late patens ostenditur."

55 Ibid., 187. "Quemmadmodum vero impudicitiae foeditas despicabilem reddit praedicatorem, ita avaritiae sordes faciunt odiosum."

$56 \quad$ Ibid., 389 .

57 According to Francisco Leonardo Lisi, this insistence on the command of Amerindian languages was one of Acosta's principal contributions to the ecclesiastical reforms of the Third Council of Lima. Francisco Leonardo Lisi, El Tercer Concilio Limense y la aculturación de los indígenas sudamericanos (Salamanca: Ediciones Universidad de Salamanca, 1990), 65 . 
to the evangelical virtues that the Jesuits' attempted to embody through their missionary activity in the Americas, this intellectual discipline, which Acosta reflects in his own meticulous and prolific works, increasingly becomes central to the order's ideal of self-mastery. This ascetic ideal, developed as a response to the problem of colonial theodicy, thus becomes a mode of symbolic action for reconciling the contradictions underlying Spanish sovereignty. The prolific Jesuit missionary hagiographies and histories published by the order throughout the seventeenth and eighteenth centuries document this self-mastery, which includes the willingness to suffer the dangers and deprivation of the colonial frontier while remaining a model of virtue and intellectual discipline.

Though a relatively understudied work within Acosta's corpus, ${ }^{58}$ his edifying letter on the life of the coadjutor Bartolomé Lorenzo, one of the earliest contributions to this canon of Jesuit missionary hagiography, vividly illustrates the conjuncture of the Jesuit ascetic ideal with a particular narrative mode as a symbolic performance that serves as a "resolution of determinant contradictions." 59

$5^{8}$ Though considered a "minor" work, Acosta's letter, written in 1586 and addressed to the Jesuit general Claudio Acquaviva (1543-1615), can perhaps stake a claim to being the most widely circulated of his writings behind the Historia natural y moral given that it was later included in Alonso de Andrade's Varones ilustres de la Compañía de Jesús (1666). As further testament to the circulation of Acosta's edifying letter, a modified version was included in the Novohispanic Jesuit Juan Antonio de Oviedo's (1670-1756) menology of the Society's distinguished coadjutors, which was published in New Spain in 1755 . In his detailed study of the publication history and content of the edifying letter, Lorenzo Rubio González recognizes its "literary form" and "providentialist character," yet he fails to connect the work to the concerns at the center of Acosta's other writings. José Juan Arrom more forcefully argues for the strictly literary character of Acosta's letter, which he places within the genealogy of the twentieth-century Latin American novel. Juan Antonio Oviedo, Elogios de algunos hermanos coadjutores de la Compañía de Jesús que vivieron, y murieron con opinión, y fama de santidad (Mexico: Imprenta de la viuda de don Joseph Bernardo de Hogal, 1755), 2:324-44. Lorenzo Rubio González, "Sobre la 'Peregrinación de Bartolomé Lorenzo' (Relato de aventuras por las Indias Occidentales)," Castilla: Estudios de literatura no. 1 (1980): 81. José Juan Arrom, "Precursores coloniales de la narrativa Hispanoamericana: José de Acosta o la ficción como biografía," Revista Iberoamericana 44, no. 104-5 (1978): 369-83.

59 I am invoking Frederic Jameson's (1934-) classic description of narrative as a socially symbolic act. Though Jameson's analysis is almost exclusively limited to the modern novel, it is nevertheless applicable to the prolific corpus of hagiographic narratives that the Society of Jesus produced for a broad reading public from the sixteenth to eighteenth centuries. The performance of the Jesuit ascetic ideal and its concomitant articulation through narrative as a model of spiritual heroism and virtue enacted against the backdrop of 
In his peregrination throughout the Caribbean, Central America, and finally the viceroyalty of Peru, where he is drawn to the example of the Jesuits, Lorenzo's eremitic love of solitude and self-denial provides a stark foil to the vices rampant among Europeans, who are not only represented by Catholic Spaniards and Portuguese but also by Lutheran French pirates. In a subtle foreshadowing to the climax of Acosta's account, Lorenzo begins his journey aboard a ship transporting African slaves from Cape Verde to Hispaniola, thus underscoring the conjunction of greed, commerce, and violence that sustained the Spanish imperial enterprise in the Americas. Acosta molds the story of Lorenzo's misfortunes and exemplary piety into a parable for his resolution of the problem of colonial theodicy: though the young Portuguese is drawn to the New World through commerce and the promise of mining wealth, these prove to be the means by which he discovers his true vocation within the Society of Jesus. In Hispaniola, Lorenzo's modest commercial and mining endeavors fail miserably, and he is forced to flee when colonial officials discover he has entered Spanish territories without permission. While Lorenzo is a witness to the marvelous natural landscapes of the Americas, for which he was an important source for Acosta's Historia natural y moral, these landscapes are likewise the refuge of escaped Amerindian and African slaves who are a reminder of the violence of the Spanish colonial system. In Jamaica, Lorenzo comes upon a solitary old man who remained hidden for twenty years from the "oppression and mistreatment of the Spaniards." ${ }^{60}$ In Panama, he is accosted by escaped slaves who have turned to banditry and murder, but who are moved by Lorenzo's simplicity, generosity, and humility. ${ }^{61}$ In perhaps the most ambiguous episode of Lorenzo's journey, he lives as a hermit for eight months in the proximity of a priest who, "with the covetousness [codicia] of losing his slaves [negros]," has followed a group of Africans who have fled into the "desert" of the Central American jungles to escape their overseer. ${ }^{62}$ When Lorenzo finally comes upon an indigenous

conflicts inherent to a given society is a consummate example of this "resolution of determinant contradictions." Frederic Jameson, The Political Unconscious: Narrative as a Socially Symbolic Act (Ithaca, NY: Cornell University Press, 1982), 66.

6o José de Acosta, Peregrinación de Bartolomé Lorenzo, in Obras de P. José de Acosta de la Compañía de Jesús, ed. P. Francisco Mateos (Madrid: Atlas, 1954), 308: "la opresión y malos tratamientos de los españoles."

61 Ibid., 311.

62 Ibid., 312-13: "con la codicia de no perder sus negros." Though this passage is confusingly written, Acosta, as elsewhere, seems to employ "codicia [covetousness or greed]" ironically: i.e., the priest was covetous of the salvation of his catechumens, who were driven away by the material greed of their Spanish overseers. Tellingly, the passage is omitted from Oviedo's eighteenth-century version. 
community that is trusting and welcoming of Spaniards, it is just prior to his arrival in Portoviejo in Ecuador, where he is promptly forced to participate in slave raids against peaceful Amerindians.

An exemplar of Christian charity and rejection of worldly comforts throughout his travails as a shipwrecked, wandering hermit, Lorenzo is dragooned into the local militia by the captain and mayor of Portoviejo, to whom he vehemently protests that "he would not endeavor to deprive anyone of their freedom, and that those Indians against whom the expedition was planned had done nothing to offend him that would justify war." ${ }^{23}$ Despite his "repugnance," Lorenzo is nevertheless forced to participate under threat of execution and bears witness to scenes of cruelty that Acosta elsewhere denounces as the underside of the "new" world order. The future Jesuit coadjutor redeems himself by saving the life of a six-year-old child and by immediately freeing the three slaves he receives as payment. When Lorenzo refuses to participate in a second slave raid and seeks refuge in a convent, a coronel is sent to compel him but ends up repenting when the hermit admonishes him to reflect upon his sins. Acosta explains that Lorenzo abandoned Portoviejo not for fear of reprisal from the mayor but rather for fear that the rest of the populace might take justice into its own hands and hang him for insulting the colonel and deserting the militia. Read in light of Acosta's other works, this episode, the most detailed in his edifying letter on the life of Brother Lorenzo, demonstrates how deeply the political, social, and economic life of the Spanish colonies was rooted in a continuous state of exception dominated by the ruthless pursuit of wealth. ${ }^{64}$

63 Ibid., 317: "que él no había de ir a quitar a nadie su libertad, y que aquellos indios, contra quien se encaminaba esa jornada, no le habían a él ofendido para que los fuese a guerrear."

64 This case of the imminent threat of mob violence as a means of upholding respect for the law exemplifies Walter Benjamin's well-known reflections on sovereign violence and the state of exception: "For the function of violence in lawmaking is two-fold in the sense that lawmaking pursues as its end, with violence as the means, what is to be established as law, but at the moment of instatement does not dismiss violence; rather, at this very moment of lawmaking, it specifically establishes as law not an end unalloyed by violence but one necessarily and intimately bound to it, under the title of power." Benjamin, Walter, "Critique of Violence," in Selected Writings, trans. Edmund Jephcott, ed. Marcus Bullock and Michael W. Jennings (Cambridge, MA: Harvard University Press, 1996), 1:248. Acosta's writings bring into relief the paradoxical nature of the sovereign decision and the state of exception as expressed by Giorgio Agamben (1942-): "The state of exception is not so much a spatiotemporal suspension as a complex topological figure in which not only the exception and the rule but also the state of nature and law, outside and inside, pass through one another." Giorgio Agamben, Homo Sacer: Sovereign Power and Bare Life, trans. Daniel Heller-Roazen (Stanford: Stanford University Press, 1998), 37. 
Acosta's edifying letter fittingly ends when Lorenzo happens upon Father Cristóbal Sánchez ${ }^{65}$ of the Society of Jesus and observes the Jesuit vocation, which is clearly distinguishable from the other religious orders:

He did not know which religious order the Society of Jesus was, nor did he have any news of the order. But he carefully watched those fathers, and he was drawn to them; and he especially took note of their great charity in not denying themselves to anybody, regardless of the low condition of the petitioner, and how they attempted to procure the salvation of all. He was also pleased by the fact that they maintained a strict reclusion at the inn, and upon seeing that they used the common habit of the clergy he was further drawn to them, as he had never liked to wear a hood. ${ }^{66}$

Lorenzo is accepted into the order as a coadjutor and becomes an edifying example to his brethren in Lima and to future members of the order through Acosta's letter, which was republished throughout the seventeenth and eighteenth centuries. Though Acosta's narrative on Brother Lorenzo lacks many aspects of the Jesuit missionary vocation in Spanish America that are prominent in seventeenth-century chronicles-particularly the gift for languages applied to the evangelization of Amerindians with no history of contact with Europeans - the story observes the increasingly familiar pattern of an ascetic ideal performed against the backdrop of vices inherent in colonial rule. Antonio Ruiz de Montoya's (1585-1652) Conquista espiritual (1639), which narrates the confrontation between Jesuit missionaries in Paraguay

65 According to the Jesuit historian Ruben Vargas Ugarte, Sánchez was a canon priest from Cuzco who joined the Society of Jesus in Lima in 1568 at the age of thirty-five. In his seventeenth-century manuscript history of the Peruvian province, Giovanni Anello Oliva (1572-1642) writes that Sánchez died ten years later (1578) in the city of Chachapoyas, where he was renowned for his saintliness. Ruben Vargas Ugarte, Historia de la Compañía de Jesús en el Perú (Burgos: Imprenta de Aldecoa, 1963), 1:53. Giovanni Anello Oliva, Historia del reino y provincias del Perú, ed. Carlos M. Gálvez Peña (Lima: Fondo Editorial Pontificia Universidad Católica del Perú, 1998), 231.

66 Acosta, Peregrinación, 320. "Él no sabía qué religión era la Compañía de Jesús, ni tenía noticia de ella; pero miró mucho a aquellos padres, y pareciéronle bien; y especialmente notó su mucha caridad en no negarse a nadie, por bajas que fuesen las personas, y que con todos trataban de su salvación. Y también le agradó mucho que a sus solas en la posada guardaban grande recogimiento, y el ver que traían hábito común de clérigos le tiró la inclinación, porque siempre se le había hecho de mal ponserse capilla." 
and slave-raiders from São Paulo, is perhaps the most captivating example of this structure already present in Acosta's brief edifying letter.

In a phrase redacted from the 1589 edition of De procuranda Indorum salute, Acosta despairs, "We are the dregs of Spain, so that it seems that we have been shipped here to free her from her garbage instead of taking charge of the government of these peoples." 67 This indictment of Spanish conduct, which seems to throw the entire civilizing and evangelizing project into doubt, is nevertheless subsumed into the Jesuit's colonial theodicy, which ultimately turns to the rationalization of colonial administration as a means to achieving a universal order that is announced by the advent of the New World yet perennially postponed. In the context of colonial Spanish America, the Jesuit vocation thus becomes a reaffirmation of order and coherence in the face of the radical evil that founds this order and remains evident in the everyday experience of the colonial world. In Acosta's providential dialectic, the scrutinizing gaze of the victim of colonial violence is only incorporated insofar as it is a reminder of this providential mission and the importance of self-discipline and mindfulness in carrying out one's duties. This reaffirmation of a global order emerging from the exception (moral evil, violence, suffering) on the expanding colonial frontier of Spanish America merits further examination within contemporary inquiries into the influence of religious ethics in the shaping of modernity.

67 Acosta, De procuranda Indorum salute, 1:413-15. "Quae Hispaniae faeces, ut illius exonerandae causa potius huc appulisse videamur quam reipublicae huius capessendae.” 